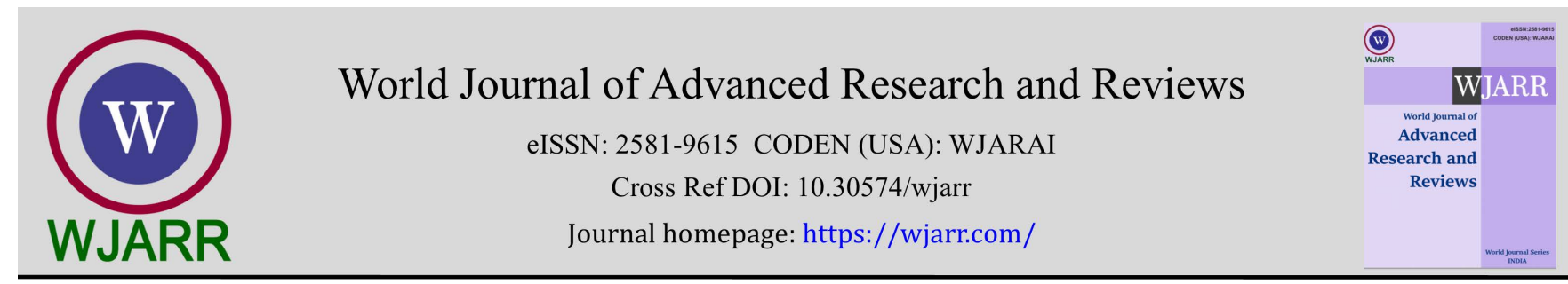

(REVIEW ARTICLE)

\title{
Intercrop practices in cashew production
}

\author{
Olufemi Aremu-Dele ${ }^{1,}{ }^{*}$, Kehinde Ademola Adesanya ${ }^{2}$, Bunmi Olaoluwa Olorundare ${ }^{3}$, Oluwadamilola \\ Ifedolapo Asunbo ${ }^{4}$ and Elizabeth Feyisayo Odeyemi ${ }^{5}$ \\ ${ }^{1}$ Department of Agronomy, Cocoa Research Institute of Nigeria, P.M.B. 5244, Ibadan, Oyo State, Nigeria. \\ 2 Department of Economics and Extension, Cocoa Research Institute of Nigeria, P.M.B. 5244, Ibadan, Oyo State, Nigeria. \\ ${ }^{3}$ Value Addition Research Department, Cocoa Research Institute of Nigeria, P.M.B. 5244, Ibadan, Oyo State, Nigeria. \\ ${ }^{4}$ Plant Protection Section, Entomology Unit, Cocoa Research Institute of Nigeria, P.M.B. 5244, Ibadan, Oyo State, Nigeria. \\ ${ }^{5}$ Value Addition Research Department, Cocoa Research Institute of Nigeria, P.M.B. 5244, Ibadan, Oyo State, Nigeria.
}

World Journal of Advanced Research and Reviews, 2021, 10(03), 281-288

Publication history: Received on 02 May 2021; revised on 14 June 2021; accepted on 17 June 2021

Article DOI: https://doi.org/10.30574/wjarr.2021.10.3.0268

\begin{abstract}
Cashew is an important economic tree crop cultivated for its wood, apple and most especially the nut. The large plant spacing involved in its cultivation encourages intercropping. Intercropping cashew during the early phase of establishment with arable and sometimes tree crops is usually practiced which serves as food security, cultural weed control and means of additional income to farmers. The aim of this study is to look into some experimented cashew intercrop and gaps in the intercrop patterns. Review of past literatures was used in discovering cashew intercrop patterns in Nigeria and some major cashew producing countries. Intercropping cashew with arable crops is more popular and profitable than with tree crop except in Sri-lanka where intercropping with coconut seems profitable than cashew sole cropping. Intercropping of cashew with arable crops, legumes and vegetables did not affect the growth of young cashew except millet, sorghum and pigeon-pea. Cashew/maize and cashew/cassava/yam had high returns respectively. Intercrop combinations with more than two crops affected the growth of cashew. Cashew/rice and cashew/plantain intercrop suppressed the growth of weeds with no negative effect on cashew growth. More concise and implementable research can be done where information on weed control, growth parameters, nutrient demands, yield and economic returns can be gotten from an experiment on the various cashew intercrop patterns as this will make the findings more adoptable by the farmers. Intercropping cashew with more than 2 crops should be discouraged.
\end{abstract}

Keywords: Cashew; Intercrop; Intercropping; Arable crops; Review; Pattern

\section{Introduction}

Cashew (Anacardium occidentale L.) which is indigenous to Brazil belongs to the family Anacardiaceae [1]. It is a perennial evergreen tree with spreading large canopies which can attain the height of 10 to 12 meters [2]. It is a hardy and drought resistant tree cultivated economically for its apple, wood and most importantly the nut in Nigeria and other major cashew producing countries such as Vietnam, Ghana, Philippines, Tanzania, Sri-Lanka and India [3]. The cashew apple comprises of about 85\% juice [4]. Apart from direct consumption of the apple, it can be processed into wines, brandy, alcohol, vinegar and fruit juice. The nuts which can be roasted and consumed as snack can be used by confectionery industries and bakeries as raw material. It is a vital foreign exchange crop thereby making it the third ranking foreign exchange provider among other crops [5].

According to Yeboah et. al., [6] cashew is commonly cultivated via seed. Cashew seeds can be planted raising the seedlings 2 to 3 months in the nursery before transplanting [7, 8]. Asexual propagation such as air layering, budding

\footnotetext{
* Corresponding author: Olufemi Aremu-Dele

Department of Agronomy, Cocoa Research Institute of Nigeria, P.M.B. 5244, Ibadan, Oyo State, Nigeria.

Copyright (C) 2021 Author(s) retain the copyright of this article. This article is published under the terms of the Creative Commons Attribution Liscense 4.0.
} 
and grafting have been tried with varying levels of success in different countries with grafting being observed to be the most appropriate for commercial clonal seedling production [3]. Two out of the most important morphological traits of cashew is the apple colour which could be either red or yellow and the nut size [9]. The nut classes are Jumbo, Extralarge, Large, Medium, Small and Madras [10]. It has been observed that cashew trees start producing fruit in the third or fourth year after establishment, and are likely to reach their mature yield potential by the seventh year [11] with maximum production of up to 10 to 30 years [12]. The numerous importance and economic value of cashew makes it a vital tree crop for rigorous research.

Intercropping is an act of cultivating two or more crops on the same piece of land simultaneously. It is widely practiced by farmers especially in tropical areas [13]. It is an advanced agro-technique and is considered to be a potent and likely means of increasing crop production per unit area and time [14], particularly for farmers with small holdings [15]. It also helps as an insurance against main crop failure under adverse condition [14]. A programed intercropping system involving compatible crops with different morphological and rooting pattern will enable better resource use and more financial returns [16]. One of the core reasons for yield increase in intercropping is that the component crops are able to use natural resources differently and make broader use of natural resources better than grown as sole [17]. Profitable intercropping majorly depends on planting form and compatibility with component crops [14]. Intercropping is also seen as cultural method of weed control. Reduction in weed biomass and weed incidence has been observed on intercropped fields [18].

This paper therefore aims at summarizing some researched cashew intercrop options and gaps in the intercrop patterns.

\subsection{Intercropping: Cashew as a case study}

Intercropping is the most practiced type of multiple cropping [19] which is carried out to provide food and additional income to farmers as an alternative source of income during early filed establishment. One of the advantages for growing Cashew is that it has the potential for intercrop due to the large plant spacing involved in its cultivation [20]. Some decades ago intercropping in cashew received little attention but has recently become popular with the systematic establishment of large-scale orchards which is usually practiced at early stages of field establishment (4-5 years) when the leaf canopies have not closed completely [11].

Intercropping which is one of the cultural methods of weed control in both arable and tree crop production has been observed to reduce weed biomass than in sole cropping in cashew $[21,18]$. This shows that aside creating an alternative source of income, it is also an effective weed control method during the early stages of cashew field establishment.

In case of sole cashew plantation, cost of weed control is high and contribution of weed control to the cost of production increases by $33 \%$ and to avoid this, the vacant space available in between two rows of crop can be effectively used for growing profitable intercrops like pineapple, turmeric, ginger and ground nut [22].

\section{Cashew based cropping systems with arable crops}

Some research has been conducted by Cocoa Research Institute of Nigeria (CRIN) on cashew as it is one of their mandate crops. Famaye et. al., [18] studied cashew/rice/plantain intercrop and its effect on weed incidence.

Table 1 Mean weed biomass of Cashew, rice and plantain intercrop

\begin{tabular}{|l|c|c|}
\hline \multirow{2}{*}{\multicolumn{1}{c|}{ Treatment }} & \multicolumn{2}{c|}{ Mean Weed Biomass (t/ha) } \\
\cline { 2 - 3 } & $\mathbf{2 0 0 7}$ & $\mathbf{2 0 0 8}$ \\
\hline Cashew sole & 25 & 17 \\
\hline Rice sole & 20 & 15 \\
\hline Plantain sole & 15 & 10 \\
\hline Cashew/rice & 13 & 10 \\
\hline Cashew/plantain & 13 & 8 \\
\hline Cashew/rice/plantain & 12 & 5 \\
\hline LSD (p=0.05) & 4.9 & 4.3 \\
\hline \multicolumn{2}{|c|}{ Source: $[18]$} & \\
\hline
\end{tabular}


It was observed that the intercrop gave higher growth parameters of cashew than in sole planting except in cashew/rice/plantain intercrop which might be due to higher competition for soil nutrient and sunlight. The result also agrees with Adeyemi, [23] who reported the superiority of growth performance of cashew in the intercropped treatments than in sole cashew. As shown in Table 1, cashew/rice and cashew/plantain gave a lower weed incidence and weed biomass without and negative effect on the main crop's (Cashew) morphological growth. This indicates that less labour is needed for weed control in a cashew intercrop system. This agrees with Olukotun, [24] who reported that intercropping cashew with arable crops will increase labor efficiency and reduce production cost. Table 2, shows the average yield of the sole and intercrop combinations. From the experiment, it was observed that the cashew/rice and cashew/plantain were better than the other intercrop or sole cropping in their morphological growth, weed control and economic yield.

Table 2 Average yield of rice and plantain in t/ha when intercropped with cashew

\begin{tabular}{|l|l|l|}
\hline \multirow{2}{*}{ Treatment } & \multicolumn{2}{c|}{ Yield (t/ha) } \\
\cline { 2 - 3 } & Grain & Bunch \\
\hline Rice sole & 2.3 & $\mathbf{}$ \\
\hline Plantain sole & $\mathbf{6}$ & 60.8 \\
\hline Cashew/rice & 2.1 & $\mathbf{0}$ \\
\hline Cashew/plantain & $\mathbf{6}$ & 60 \\
\hline Cashew/rice/plantain & 1.8 & 59.5 \\
\hline LSD (p=0.05) & 2.1 & 60.1 \\
\hline \multicolumn{2}{|c}{ Source: [18] } \\
\hline
\end{tabular}

Lawal et. al. [11] observed that intercropping cashew with maize, cowpea, cassava/yam and vegetable is a common practice among cashew farmers in Nigeria. The revenue from the cashew/maize intercrop generated the highest revenue followed by cashew/cassava/yam. Cashew/vegetable and cashew/cowpea had a relatively low profit margin as cowpea and vegetable did not contribute significantly to the total profit from the intercrop. Heavy consumption of cowpea and vegetable by farmers household might have contributed to this. This agrees with the findings of Singh et. al., [25] who observed reduction in the yield of vegetables when intercropped with guava. Maize and cowpea contributed significantly to the total profit realized from the intercrop. It is profitable to intercrop in cashew plantation because of the low expenditure and high returns involved before the economic yield of cashew begins. This correlates with the findings of Lawal et. al., [26] on the gains of value addition in cashew that the activities on cashew plantation bring much gain to farmers and their household.

Table 3 Cashew intercrop revenue

\begin{tabular}{|l|c|c|}
\hline \multicolumn{1}{|c|}{ Variables } & Mean & Standard Deviation \\
\hline Age of farmer & 48,84 & 12.57 \\
\hline Year of cashew farming experience & 23.26 & 8.49 \\
\hline Age of cashew trees & 17.94 & 9.27 \\
\hline Household size & 5 & 2 \\
\hline Farm size & 2.09 & 1.14 \\
\hline Total Revenue & $1,109,237.14$ & $18,390,99$ \\
\hline Total Expenditure & $47,084.00$ & $5,134.02$ \\
\hline Intercrop Revenue & & \\
\hline Maize & $95,666,67$ & $34,826,56$ \\
\hline Cowpea & $13,573.33$ & $11,828.19$ \\
\hline Cassava/Yam & $50,066.67$ & $18,167.34$ \\
\hline Vegetable & $5,742.86$ & $4,007.02$ \\
\hline \multicolumn{2}{|c|}{ Source: $[11]$} \\
\hline
\end{tabular}


Seven systems of intercrop were developed by Adeyemi, [21] which involve intercropping cashew with 1 or 2 arable crops simultaneously which were cashew/cassava, maize/plantain, cashew/maize/cassava, cashew/maize/cowpea, cashew/cassava, cashew/maize/plantain, cashew/cassava/plantain, cashew/plantain. It was observed that cashew in cashew/cassava/maize and cashew/plantain was not significantly different from the result obtained from cashew sole cropping in terms of growth parameters. Cashew in cashew/cassava/maize/plantain, cashew/maize/cowpea and cashew/cassava/plantain combinations didn't perform well in terms of growth parameters which might be due to the heavy demand for soil nutrient due to completion among the crops. Nonetheless, findings on cropping systems have shown some negative effect on vegetative and flowering of crops in the intercrop compared with sole crops [27, 28, 29]. All the combinations did not influence the survival of cashew negatively as they all had $100 \%$ survival rate except cashew/cassava/maize/plantain and cashew/cassava which both had 87.5\%. Table 4 below shows the number of weeding done per annum. Labour and cost of weeding is low in cashew/cassava, cashew/cassava/maize/plantain and cashew/maize/ cassava compared to cashew/maize/cowpea cashew/plantain and cashew alone with very high weeding periods. This corresponds with the findings of [30] that intercropping is a way of reducing weed infestation challenges. Enough details were not given on the yield of this intercrop system where further tangible conclusions would have been made. This is a challenge because intercrop patterns have variable effect on yield of component crops [31].

Table 4 No. of weeding in cashew based intercropping system.

\begin{tabular}{|l|c|}
\hline \multicolumn{1}{|c|}{ Cropping Systems } & No. of weeding per annum \\
\hline Cashew/Cassava/Maize/Plantain & 2 \\
\hline Cashew/Maize/Cassava & 2 \\
\hline Cashew/Maize/Cowpea & 7 \\
\hline Cashew/Cassava & 1 \\
\hline Cashew/Maize/Plantain & 6 \\
\hline Cashew/Cassava/Plantain & 4 \\
\hline Cashew/Plantain & 8 \\
\hline Cashew sole & 8 \\
\hline
\end{tabular}

Table 5 Effects of intercropping arable crops with young cashew seedlings on the performance of the companion crops

\begin{tabular}{|c|c|c|c|c|c|c|c|}
\hline \multirow[b]{2}{*}{ Treatment } & \multicolumn{5}{|c|}{ Growth Parameters } & \multicolumn{2}{|c|}{ Yield } \\
\hline & $\begin{array}{l}\text { Seedling } \\
\text { Survival } \\
(\%)\end{array}$ & $\begin{array}{l}\text { Leaf } \\
\text { No. }\end{array}$ & $\begin{array}{l}\text { Leaf } \\
\text { Area } \\
(\mathrm{cm} 2)\end{array}$ & $\begin{array}{l}\text { Stem } \\
\text { Height } \\
\text { (cm) }\end{array}$ & $\begin{array}{l}\text { Stem } \\
\text { Girth } \\
(\mathrm{cm})\end{array}$ & $\begin{array}{l}\text { Maize } \\
\text { Yield } \\
\text { (kg/ha) }\end{array}$ & $\begin{array}{l}\text { Bambara } \\
\text { Nut Yield } \\
\text { (kg/ha) }\end{array}$ \\
\hline Cashew sole & 83.5 & 10.85 & 24.41 & 26.85 & 0.51 & ש & ש \\
\hline Cashew/Maize & 69.5 & 11.98 & 28.27 & 31.13 & 0.53 & 502.04 & $\square$ \\
\hline Cashew/Cassava & 58.5 & 13.25 & 33.7 & 28.56 & 0.49 & $\square$ & $\mathbf{\square}$ \\
\hline Cashew/Bambara & 61.25 & 15.07 & 29.38 & 27.69 & 0.51 & $\square$ & 496.87 \\
\hline Cashew/Maize/Cassava/Bambara & 58.25 & 13.07 & 28.2 & 30.27 & 0.54 & 536.13 & 303.7 \\
\hline Maize sole & $\square$ & $\mathbf{a}$ & 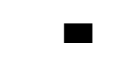 & $\mathbf{a}$ & $\mathbf{a}$ & 629.51 & $\mathbf{a}$ \\
\hline Bambara Nut sole & 口 & $\mathbf{\square}$ & $\mathbf{\square}$ & $\mathbf{\square}$ & $\mathbf{\square}$ & 口 & 491.71 \\
\hline S.E. & 13.36 & 3.92 & 12.02 & 3.09 & 0.07 & 123.63 & 95.77 \\
\hline
\end{tabular}


Olukotun, [24] observed that cashew/cassava, cashew/maize, cashew/bambara intercrop did not have negative effect on the development of the cashews seedlings as shown in Table 5 as the crops did not affect the growth parameters of cashew. This agrees with the observation of Adiga and Kalaivanan, [32]. This shows that cashew can grow well when intercropped with these crops. This was the main report from his findings as there wasn't enough information given on the yield performance of the crops to draw to a conclusion on which intercrop gave the highest yield.

\section{Cashew based cropping systems with tree crops}

Uwagboe et. al. [33] observed cashew farmers in Kogi state where cashew is heavily cultivated in Nigeria noticed that cashew intercropped with kola, mango and citrus is not a common practice. The few cashew farmers who practices the intercrop makes very low income from these crops basically due to poor market, irregular market prices of the middle men and small land holdings. Out of the tree crops not commonly intercropped with cashew, oil palm seems to be the most popular which is cultivated to an extent compared to the other tree crops. Report later emphasized that kola, mango, citrus and oil palm did not significantly contribute to the yield revenue of cashew to the farmers.

In Oyo state, intercrop with other tree crops is not popular as they are majorly planted as sole or intercropped with arable crops and vegetables [11].

\section{Cashew based cropping systems in some cashew producing countries}

\subsection{Ghana}

In Ghana, Opoku-Ameyaw et. al., [34] checked the growth and early yield of cashew intercropped with some food crops such as groundnut, maize, sorghum, yam, the combination of cashew + sorghum in rotation with groundnut and the combination of cashew + groundnut in rotation with maize. It was reported that all the intercrop options did not significantly affect early yield of cashew nuts which indicated that food crop intercropping during the early phase of establishment may not have detrimental effect on cashew yield. The economic analysis showed that maize and yam intercropped with cashew during this period was profitable.

\subsection{Sri-Lanka}

In Sri-Lanka, coconut and cashew cultivation is common among the farmers. Ginigaddara, et. al., [35] looked into the technical feasibility of coconut and cashew intercropping systems. The result showed that there was a wide gap between yields in coconut and cashew sole cropping and when intercropped as yields were reduced to $49 \%$ and $30 \%$ in coconut and cashew respectively in an intercrop system. Though the economic implication of the combination of yield in the intercrop system is higher than in sole cropping of either coconut or cashew. This agrees with the report of Ahmad and Rao, [36] that intercropping gives more aggregate yield and financial returns than from sole cropping. A shortcoming of this intercrop pattern is that it involves erroneous agronomic practices and labour which increases cost of production thereby reducing profit. This agrees with the report of Hong et. al., [37] that intercropping can be labour intensive. Another is that, in this intercropping system, the focus is not to grow coconut during the early stages of establishment of cashew for revenue generation as both crops are perennial in nature and tends to fruit almost the same time.

Another experiment was carried out in Sri-Lanka on intercropping of cashew with maize, pigeon pea, groundnut, cowpea, mungbean and sesame which are all arable crops. It was observed that intercropping of cashew with the selected arable crops has no deleterious impact on the growth, development and yield of cashew in its early phase of establishment except pigeon pea. Maize and groundnut in the Maha season (October to March) and sesame in the Yala season (April to September) as intercrop with cashew does not affect the development of cashew and LER was higher in the intercropping systems than sole cashew cultivation [38].

\subsection{India}

In India which is one of the leading cashew producers in the world, Gajbhiye et. al., [39] researched on intercropping different vegetable crops in new cashew plantation. The vegetables are yardlong bean, cowpea, chilli, behendi and brinjal. It was observed that canopy formed by the vegetable did not affect the growth, flowering and fruiting of the cashew but highest yield of cashew was recorded in cashew + yardlong bean intercrop while cashew + cowpea followed. Yardlong bean and cowpea are leguminous nitrogen fixing crops. Their ability to make atmospheric Nitrogen available to cashew in the intercrop system could be responsible for the higher yield. Cashew + Bhendi performed the least due to the incidence of yellow vein mosaic. Yardlong bean also had the best yield and highest Land Equivalent Ratio out of 
the five vegetables. The best combination is cashew + Yardlong besan has it had the best total yield and gave the best economic returns.

Vikram and Hegde, [40] observed the performance of turmeric in cashew plantation compared to sole cropping. It was discovered that higher yield of turmeric was observed in sole turmeric than when intercropped with cashew though turmeric intercropped with cashew had better growth morphologically than sole turmeric cropping which is due to the shade loving nature of turmeric plants.

\subsection{China}

Recently, cashew is being intercropped in some regions of china with watermelons, sweet-melons and vegetables [41] unlike before when intercropping cashew with green cover crops and short-term annual crops is very common [32].

\subsection{Vietnam}

Farmers with large farm sizes for cashew cultivation most times intercrop with arable crops such as maize, beans, and cassava for personal use and sometimes for sale. Aside food production, intercropping with leguminous crops is also encouraged to reduce the effect of erosion on slopes and also to enhance soil structure [32].

\section{Conclusion}

This review looked into various experimented intercrop systems in cashew-based production. It was observed that most of these experiments did not give an encompassing details on the cashew intercrop systems as focus were either on weed control, cost of production, economic implication, yield and growth of crops. A cashew based intercrop system with an effective weed control capability does not necessarily guarantee profitability. An Intercrop system with the crops exhibiting good growth parameters does not necessarily guarantee profitability. Therefore there is a need for a more concise research on these intercrop systems for a more implementable and adoptable cashew based intercrop system based on profitability since the main aim of the farmers is to generate income while the main crop (cashew) is not yet productive.

Intercropping cashew with more than two crops had negative effect on the growth of the young cashew seedling in all the intercrop patterns considered therefore it is encouraged to limit the intercrop to cashew and at most 2 crops This will also help to reduce the demand on soil nutrients.

In Nigeria and few other cashew producing countries, intercrop of cashew with tree crops is not a common practice and does not add significant income to the farmers. For the purpose of other tree crops or cash crop production, there is a need for the government to implement policies that will make more farmland available for farming, improve marketing and pricing of tree crops since these seems to be some of the challenges faced by few farmers who intercrop other tree crops with cashew so as to make it attractive and also increase farmers income.

Although a variety of crops such as maize, cassava, groundnuts, soybeans, yams, and cowpea are grown with cashew, there is virtually little or no information on the nutrient demands of these crops on the soil in an intercrop system. Information on the nutrient demand of these intercrop systems will help in applying fertilizer effectively thereby improving the yield and profitability of the intercrop system.

\section{Compliance with ethical standards}

\section{Acknowledgments}

Special thanks to my co-authors for their input toward the success of this paper.

\section{Disclosure of conflict of interest}

The authors declare no conflict of interest.

\section{References}

[1] Asogwa EU, Hammed LA, Ndubuaku TCN. Integrated production and protection practices of cashew (Anacardium occidentale) in Nigeria. Afr. J. Biotechnol. 2008; 7: 4868- 4873. 
[2] Toschi TG, Caboni MF, Penazzi G. A study on cashew nut oil composition. J Am Oil Chem Soc. 1993; 70: 10171020.

[3] Adeigbe 00, Olasupo FO, Adewale BD, Muyiwa AA. A review on cashew research and production in Nigeria in the last four decades. Academic Journal. 2015; 10(5): 196-209.

[4] Sobhana A, Mathew J, Mini C, Pushpalatha PB. Technologies for cashew apple utilization on commercial scale. Souv. Nat. Conf. Cashew. 20-21 November 2013; 65-71.

[5] Rao EVVB, Nagaraja KV. Studies report on cashew. Souvenir. International conference on plantation crops. 12-15 December 2000; $1-7$.

[6] Yeboah J, Dadzie AM, Segbefia MAD, Lowor ST, Agene VN, Osei-Akoto S, Owuse-Ansha F, Banful BKB, Atuah L. Vegetative Propagation of Cashew (Anacardium occidentale L.) by Softwood Grafting in Ghana. Journal of Agricultural Science. 2020; 12(8).

[7] Opoku-Ameyaw K, Amoah F, Oppong F, Agene V. Determination of optimum age for transplanting cashew (Anacardium occidentale) seedlings in Northern Ghana. Afr. J. Agric. Res. 2007; 7: 296- 299.

[8] Hammed L, Olaniyan A, Lucas E. Field Establishment of Cashew (Anacardium occidentale L.) Transplants as Affected by Nursery Periods. J. Agric. Sci. Tech. 2012; 2(11B): 11581164.

[9] Aliyu OM. Pollen-style compatibility in cashew (Anacardium occidentale L.). Euphytica. 2007; 158: 249-260.

[10] Adeigbe 0, Adewale BD, Muyiwa AA, Olasupo FO, Olaniyi O0, Adenuga 00, Williams OA, Aliyu OM. Quantitative descriptors of cashew nut categories in nigeria: providing indices for superior nut selection. ARPN Journal of Agricultural and Biological Science. 2016; 11(4): ISSN 1990-6145.

[11] Lawal J0, Uwagboe EO. Cost Effectiveness of Intercropping Patterns by Cashew Farmers in Oyo State, Nigeria. International Journal of Forest, Animal and Fisheries Research (IJFAF). 2017; 1(1).

[12] Dorthe J. Information about cashew nut. Danida Forest Seed Centre. 2003.

[13] Ibeawuchi II. Intercropping - A Food Production Strategy for the Resource Poor farmers. Nature and Science. 2007; 5(1).

[14] Seran TH, I Brintha. Study on biological and economic efficiency of Radish (Raphanus sativus L.) intercropped with vegetable amaranthus (Amaranthus tricolor L.). Open Hortic. J. 2009; 2: 17-21.

[15] Maitra S, Hossain A, Brestic M, Skalicky M, Ondrisik P, Gitari H, Brahmachari K, Shankar T, Bhadra P, Palai JB, Jena J, Bhattacharya U, Duvvada SK, Lalichetti S, Sairam M. Intercropping-A Low Input Agricultural Strategy for Food and Environmental Security. Agronomy. 2021; 11: 343.

[16] Salam MA, Peter KV. CASHEW - A Monograph. Studium Press (India) Pvt. Ltd, New Delhi-110 002. 2010; 282.

[17] Willey RS. Intercropping - its importance and research needs. Part 1. Competition and yield advantages. Field Crop Abstracts. 1979; 32: 1-10.

[18] Famaye AO, Adeyemi EA. Effect of cashew/rice/plantain intercropped on Weed incidence in Edo State, Nigeria. ARPN Journal of Agricultural and Biological Science. 2011; 6(6).

[19] Famaye AO. A handbook on kola production. 2012; ISBN: 978-02-552-0.

[20] Carr MKV. The Water Relations and Irrigation Requirement of Cashew. Expl Agric. 2014; 50(1): 24-39.

[21] Adeyem IAA. Farming system in some CRIN scheduled crops. Growth and performance of cacao and cashew, intercropped with food crops. CRIN Annual Seminar. 17 May 1989.

[22] Yadukumar N. Development of suitable cashew-based cropping systems- inter and mixed cropping with cashew. Proceedings of the National seminar on Research, Development and Marketing of Cashew. 2007; 20-21st November, ICAR, Research Complex, Goa. 62.

[23] Adeyemi AA. Cashew/arable crops intercropping trial. 1985. Cocoa Research Institute of Nigeria (CRIN) Annual Report. 1985; 95.

[24] Olukotun OA. Intercropping of cashew with food crops. CRIN Annual Report. 1983; 42.

[25] Singh SK, Raghuvanshi M, Singh PK, Prasad J. Performance of vegetable crops as intercrops with guava plantation. Res. Environ. Life Sci. 2014; 7(4): 259- 262. 
[26] Lawal JO, Oduwole 00, Shittu TR, Muyiwa AA. Profitability of value addition to cashew farming households in Nigeria.African Crop Science Journal. 2011; 19(1): 49-54.

[27] Olaniyan AA, Fagbayide JA, Oladapo MO, Amih CA. Productivity of Cleopatra mandarin rootstock seedlings intercropped with cucumber, Asian J. Plant Sci. 2006; 5: 534-536.

[28] Olubode 00, Aiyelaagbe IOO, Bodunde JG. Effect of stage of introduction on performance of okra as an intercrop in pawpaw orchards, Biological Agriculture Horticulture. 2012; 28: 61-70.

[29] Olubode 00, Aiyelaagbe IOO, Bodunde JG. Responses of" Sunrise Solo" pawpaw, okra and cucumber components of pawpaw-based cropping system to time of intercropping, Sci. Hortic. 2012; 139: 71-78.

[30] Vandermeer JH. The ecology of intercropping. Cambridge University Press. 1989. ISBN: 9780511623523.

[31] Thomas Ubini C, Obanna Jaymiwhie, Patrick Ikogbo B. Efficacy of intercropping pattern in reducing weeds infestation in okra, maize and pepper intercrop. International Journal of Weed Science and Technology. 2018; 2(1): 063-069.

[32] Adiga JD, Kalaivanan D. Cashew Based Cropping Systems. Cashew Improvement, Production and Processing. 2017; 277-293.

[33] Uwagboe EO, Agbebaku EEO, Agbongiarhuoyi AE, Orisasona TM, Asowata FE. International Journal of Forest, Animal and Fisheries Research (IJFAF). 2017; 1(1).

[34] Opoku-Ameyaw K, Oppong FK, Amoah FM, Osei-Akoto S, Swatson E. Growth and early yield of cashew intercropped with food crops in northern Ghana. Journal of Tropical Agriculture. 2011; 49(1-2) : 53-57.

[35] Ginigaddara GAS, Fernando APS, Wijethunga PMAPK. Technical feasibility of Coconut (Cocos nucifera) Cashew (Anacardium occidentale) Intercropping System in Puttalam District, Sri Lanka. International Journal of Advanced Scientific Research and Management. Oct 2016; 1(10).

[36] Ahmad S, MR Rao. Performance of maize-soybean intercrop combination in the tropics: Results of a multilocation study. Field Crops Res. 1982; 5: 147-161.

[37] Hong Yu, Heerink Nico, Jin Shuqin, Berentsen Paul, Zhangd Lizhen, Wopkevan der Werfe. Intercropping and agroforestry in China - Current state and trends. Agriculture, Ecosystems \& Environment. 2017; 244: 52-61.

[38] Abeysinghe DC, Sangakkara UR, Jayasekera SJBA. Intercropping.of Young Cashew (Anacardium occidentale L.) and Its Effects on Crop Productivity and Land Utilization. Tropical Agricultural Research. 2003; 15: 10-19.

[39] Gajbhiye RC, Pawar SN, Zote VK, Sawant BN. Intercropping of Different Vegetable Crops in New Cashew Plantation under Konkan Conditions of Maharashtra, India. Int.J.Curr.Microbiol.App.Sci. 2020; 9(6): 448-455.

[40] Vikram HC, Hegde NK. Performance of turmeric in cashew plantation as Intercrop compared to sole cropping. The Asian Journal of Horticulture. 2014; 9(2): 496-499.

[41] Liu Kangde, Liang Shibang, Deng Suisheng. Integrated Production Practices of Cashew in China. Integrated Production Practices of Cashew in Asia (edited by Minas K. Papademetriou and Edward M. Herath). Food and Agriculture Organization of The United Nations, Regional Office for Asia and the Pacific, Bangkok, Thailand. 1998. 